\title{
Percent Below Poverty
}

National Cancer Institute

\section{Source}

National Cancer Institute. Percent Below Poverty. NCI Thesaurus. Code C53336.

The fraction of a population whose income is less than that considered sufficient for survival. 